\title{
SIMILARITIES BETWEEN EMPEROR CHANDRAGUPTA II (VIKRAMADITYA) AND EMPEROR JALALUDDIN MUHAMMAD AKBAR
}

\author{
Rajesh Sonkusare \\ Assistant Professor (History), Mhr. Sharad Pawar College of Art, Commerce and Science \\ R.T.M.Nagpur University, Nagpur
}

Article DOI: https://doi.org/10.36713/epra7289

DOI No: 10.36713/epra7289

\begin{abstract}
In the history of a great country like India, there have been many rulers since ancient times who ruled different regions of India at different times. But few of these rulers are called great rulers. Maurya ruler Chandragupta Maurya and Emperor Ashoka, Gupta ruler Chandragupta II (Vikramaditya), Vardhana ruler Harshavardhana, Kushan emperor Kanishka, Satavahana ruler Gautamiputra Satkarni, Chalukya ruler Pulakeshi II, Chola rulers Rajaraja Chola and Rajendra Chola, Rashtrakuta ruler Amoghvarsh, Pratihar ruler Mihira bhoja, Mughal emperor Jalaluddin Muhammad Akbar are named.

Among these great rulers of India were two rulers whose lives and work were very similar. The rulers were the Gupta emperor Chandragupta II (Vikramaditya) and the Mughal emperor Jalaluddin Muhammad Akbar.

The similarity between Chandragupta II (Vikramaditya) and Jalaluddin Mohammad Akbar is that the grandfather of both the rulers was the real founder of their kingdom. Both the rulers came to power through struggle (war). Both the rulers were tolerant rulers. The empire of the two rulers extended from present day Pakistan in the north to the mouth of the river Narmada in the south and from the mouth of the river Ganga in the east to the mouth of the river Indus in the west. Art, architecture, etc. developed during the reign of both the rulers. Due to the excellent administrative system of both the rulers, their empire remained stable for many generations to come. The main similarity between the two rulers is that in the history of India, only this two rulars have the Navratna in their court.
\end{abstract}

KEYWORDS : Chandragupta II (Vikramaditya), Jalaluddin Muhammad Akbar, Navaratna, Babar, Chandrahupta I, Samudragupta, Humayun, Hemu (Hemchandra), Rudrasen III.

\section{INTRODUCTION}

India had many small and large states since ancient times. The ruler who rules over those kingdoms is usually called a king. In ancient times, the king was called by different titles in different parts of India. Such as Virat in North India, Bhoj in South India, Samrat in East India, Swarat in West India and Raja in Central India. Later, in medieval times, kings were referred to as Sultans and Badshaha. The Maratha kings were referred to as Chhatrapati. Thus many rulers (kings) came to different parts of India at different times.

Some of the rulers of India have become famous as great rulers

That is

Maurya ruler Chandragupta Maurya and Emperor Ashoka,

Gupta ruler Chandragupta II (Vikramaditya),

Vardhana ruler Harshavardhana,

Kushan emperor Kanishka,
Satavahana ruler Gautamiputra Satkarni,

Chalukya ruler Pulkeshi II,

Chola rulers Rajaraja Chola and Rajendra Chola.

Rashtrakuta ruler Amoghvarsh,

Pratihara ruler Mihira bhoja,

Mughal emperor Jalaluddin Muhammad Akbar,

Maratha ruler Chhatrapati Shivaji and Chhatrapati Sambhaji ..... etc

During his reign, these great rulers performed many public works, protected the people of the state from enemies and during their time, art, literature, architecture .... Etc. developed.

But two of these great rulers of India had a great deal in common in their lives and work. The rulers were the Gupta emperor Chandragupta II (Vikramaditya) and the Mughal emperor Jalaluddin Muhammad Akbar. 
Gupta Emperor Chandragupta II (Vikramaditya) (380 AD to 415 AD) :

Chandragupta II was the son of the Gupta emperor Samudragupta and the grandson of Chandragupta I. Emperor Chandragupta II was the most powerful emperor of the Gupta Empire in the Indian Subcontinent. During his reign of 380 AD to 415 $\mathrm{AD}$, the Gupta Empire flourished in every field.

Mughal Emperor Jalaluddin Muhammad Akbar (1556 AD to $1605 \mathrm{AD})$ :

Emperor Jalaluddin Muhammad Akbar was the son of Mughal emperor Humayun and grandson of Babur. Jalaluddin Muhammad Akbar was the most powerful emperor of the Mughal Empire in the Indian subcontinent. During his reign of $1556 \mathrm{AD}$ to 1605 AD, the Mughal Empire developed.

Similarities between the Gupta Emperor Chandragupta II (Vikramaditya) and the Mughal Emperor Jalaluddin Muhammad Akbar :

The Gupta Emperor Chandragupta II (Vikramaditya) and the Mughal Emperor Jalaluddin Muhammad Akbar both ruled India at different times. But there are striking similarities between the two. They are as follows :

1. The real founder of the Gupta Empire in India of the Gupta Emperor Chandragupta II (Vikramaditya) was his grandfather Chandragupta I, while the real founder of the Mughal Empire in India of the Mughal Emperor Jalaluddin Mohammad Akbar was his grandfather Babur.

2. Chandragupta II (Vikramaditya) became the emperor of the Gupta Empire by defeating the Shaka king Rudrasen III, while Jalaluddin Muhammad Akbar became the emperor of the Mughal Empire by defeating Adilshah Suri's general Hemu (Hemchandra)

3. The empire of both the Gupta emperor Chandragupta II (Vikramaditya) and the Mughal emperor Jalaluddin Muhammad Akbar stretched from the mouth of the river Ganga in the east to the mouth of the river Indus in the west, present day Pakistan and Kashmir in the north to the valleys of the river Narmada in the South.

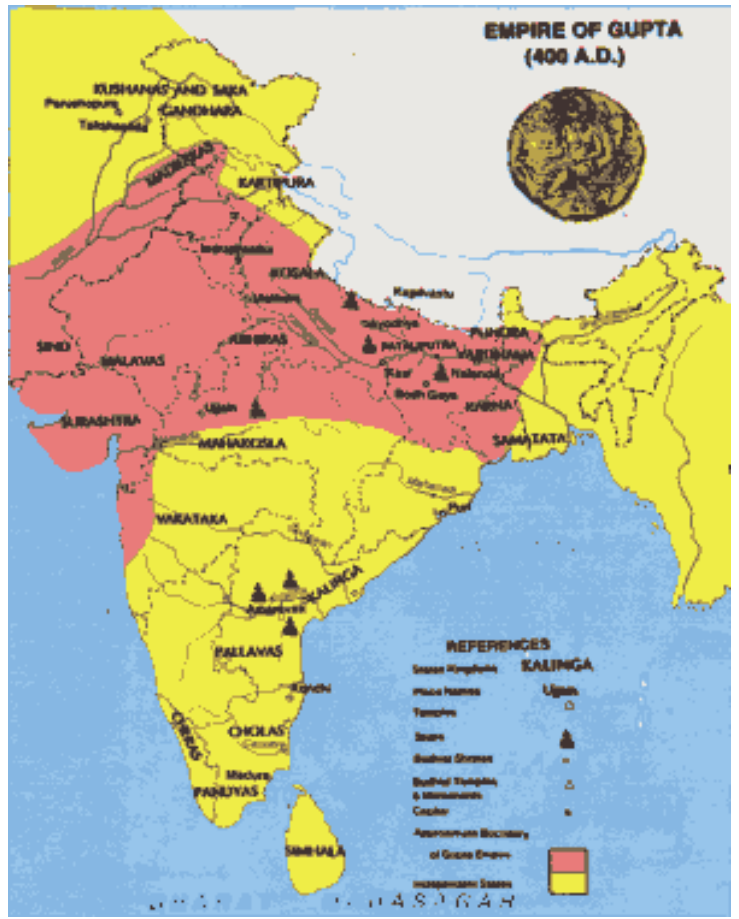

Empire of Chandragupta II (Vikramaditya) 400 A.D.

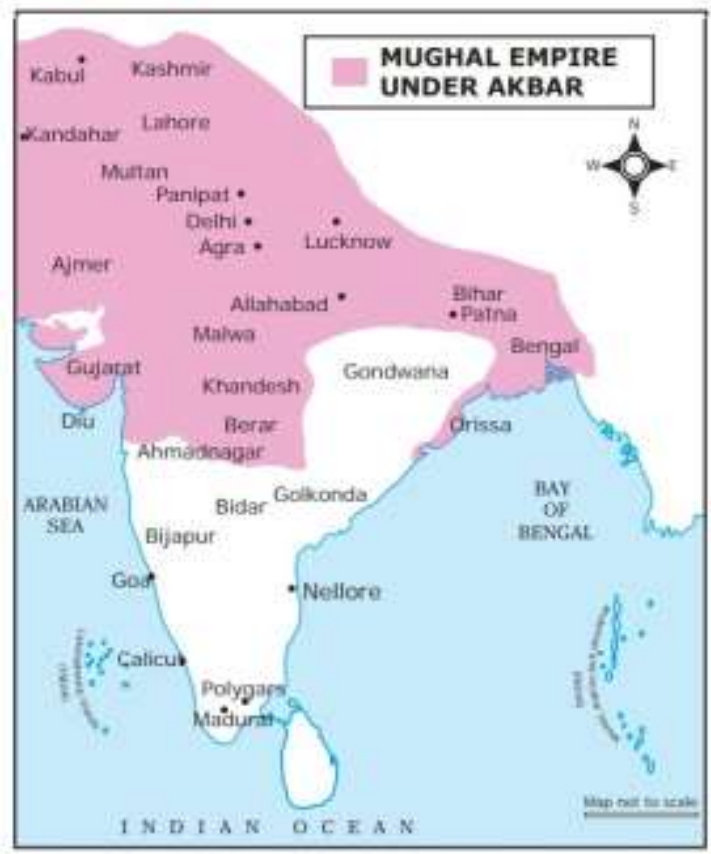

Jalaluddin Muhammad Akbar Empire 1600 A.D.

4. The Gupta emperor Chandragupta II (Vikramaditya) and the Mughal emperor Jalaluddin Muhammad Akbar were both known as tolerant rulers. The Gupta emperor Chandragupta II (Vikramaditya) was a Vaishnava of Hinduism. Yet he pursued a tolerant policy towards Shaivism, 
Buddhism and Jainism. The Mughal emperor Jalaluddin Muhammad Akbar was a Sunni Muslim. However, he adopted a tolerant policy towards Shia Muslims, Hinduism, Sikhism, Buddhism, etc.

5. The Gupta Emperor Chandragupta II (Vikramaditya) and the Mughal Emperor Jalaluddin Mohammad Akbar were the only two rulers who were able to rule for many generations to come.

6. The Gupta Emperor Chandragupta II (Vikramaditya) and the Mughal Emperor Jalaluddin Mohammad Akbar both encouraged the development of art, literature, architecture, etc. during their rule.

7. In the history of India, Navratna was in the court of both the Gupta emperor Chandragupta II (Vikramaditya) and the Mughal emperor Jalaluddin Mohammad Akbar.

Navratna in the court of Emperor

Chandragupta II (Vikramaditya) :
1. Amarasimha
2. Dhanvantari
3. Ghatkharpar
4. Kalidasa
5. Kshapanaka
6. Shanku
7. Varahamihira
8. Vararuchi
9. Vetala-Bhatta

Navratna in the court of Emperor Jalaluddin Mohammad Akbar :
1. Abul-Fazal
2. Raja Todar Mal
3. Abdul Rahim Khan-I-Khana
4. Raja Birbal (Mahesh Das)
5. Faizi
6. Fakir Aziao-Din
7. Tansen
8. Raja Man Singh I
9. Mulla Do-Piyaza

Differences Differences between the Gupta Emperor Chandragupta II (Vikramaditya) and the Mughal Emperor Jalaluddin Muhamad Akbar :

1. The Gupta emperor Chandragupta II (Vikramaditya) was a Hindu religious ruler while the Mughal emperor Jalaluddin Mohammad Akbar was a Muslim religious ruler.

2. The Gupta Emperor Chandragupta II (Vikramaditya) was a famous ruler of ancient India, while the Mughal emperor Jalaluddin Muhammad Akbar was a famous ruler of medieval India.

3. Samudragupta, the father of the Gupta emperor Chandragupta II (Vikramaditya), was a successful Chakravarti emperor, while Humayun, the father of the Mughal emperor Jalaluddin Muhammad Akbar, was a failed emperor.

\section{CONCLUSION}

There are many examples in history of two people living the same life. But there are very few examples of two famous and great leaders having the same life.

E.g. Gautam Buddha, the founder of Buddhism and Vardhman Mahavira, the founder of Jainism, Abraham Lincoln and John F. Kennedy, the president of the United States, Chandragupta II (Vikramaditya), the Gupta emperor, and Jalaluddin Muhammad Akbar, the Mughal emperor... etc.

Gautam Buddha, the founder of Buddhism, and Vardhman Mahavira, the founder of Jainism, were in the same situation at the same time. Presidents Abraham Lincoln and John F. Kennedy were 100 years apart. But the two US presidents were in the same era and the situation in the US was similar during their rule.

But there was a gap of about 1200 years between the reigns of the Gupta emperor Chandragupta II (Vikramaditya) and the Mughal emperor Jalaluddin Muhammad Akbar. Chandragupta II (Vikramaditya) was the ruler of ancient India while Jalaluddin Muhammad Akbar was the ruler of medieval India. However, despite the distances and different circumstances of an era, there are significant similarities in the lives and work of thse two rulers.

\section{REFERENCES}

1. The Gupta Empire, By Radhakumud Mookerji

2. Ancient India, By R.C.Mujumdar

3. Akbar The Great Mugal, By Vincant Arthur Smith

4. Akbar, Emperor of India, By Richard Van Garbe

5. History of Medieval India, By Satish Chandra

Web Site : https://en.wikipedia.org > wiki > Gupta_Empire

Web Site : https://en.wikipedia.org/wiki/Akbar 